\title{
A law in time?
}

\author{
Congress must act quickly to save US stem-cell research.
}

1 uman embryonic-stem-cell research in the United States has been dealt a potentially devastating blow by a federal judge, who last week issued an injunction halting US government funding for the research until a lawsuit challenging its legality is decided (see page 12). The Department of Justice vowed to speedily appeal against the injunction, but had not done so as Nature went to press. Unless the injunction is quickly reversed, and unless the government then prevails when the case is heard on its merits, hundreds of experiments funded by the National Institutes of Health (NIH) will be crippled, and many will have to be abandoned.

Scientists, patients and others who care about the survival of a highly promising area of biomedical research should not expect the courts to act in their favour. The US Court of Appeals for the District of Columbia Circuit, where the NIH's appeal will be heard, is dominated by conservatives, who are likely to sustain last week's injunction, as is the US Supreme Court.

In any case, Congress should not leave to the courts a case in which the public, on both sides of the debate, has so much invested, and which so clearly calls out for lawmakers to clarify what they intend by the amendment at the heart of the crisis. Since 1996, the DickeyWicker Amendment has been attached annually to the bill that funds the NIH. It bars federal funding for research in which human embryos are destroyed or discarded. Although it originated several years before human embryonic stem cells were isolated, Congress has repeatedly reapproved it, even as the therapeutic potential of human embryonic-stem-cell research has become evident.

At the same time, government lawyers have read Dickey-Wicker to apply only to the act of deriving stem cells, and not to research on those cells. Enabled by explicit policies from George W. Bush and, more recently, Barack Obama, Congress has funded roughly $\$ 550$ million in human embryonic-stem-cell research since 2002. Yet the district court judge who ruled last week said that Dickey-Wicker is "unambiguous" in its intent to bar such funding. "This prohibition encompasses all 'research in which' an embryo is destroyed, not just the 'piece of research' in which the embryo is destroyed," he wrote. His interpretation of Congress's intent, whatever its impact, is at least as plausible as the split between derivation and subsequent research that has formed the basis for government policy during the past decade.

Congress is highly unlikely to overturn Dickey-Wicker, which touches directly on abortion politics. Yet polls show that $50-60 \%$ of Americans, including many who oppose abortion, are sympathetic to government funding for human embryonic-stem-cell research. For NIH funding to continue, lawmakers need to pass a separate bill clarifying their intent to fund the research.

Congress is unlikely to have a huge appetite for a bruising, highly polarizing debate in the weeks immediately preceding November's midterm elections. Yet time is of the essence, and a great deal is at stake. The House may revert to Republican control in November, in which case action to affirm the funding would be highly unlikely.

A bill introduced in the House of Representatives in March by Diana DeGette (Democrat, Colorado) provides a starting point. It may need strengthening to withstand the court challenges from opponents of the research that will undoubtedly follow if it becomes law. It spells out clearly that "notwithstanding any other provision of law" (read: Dickey-Wicker), the government shall conduct and support research using human embryonic stem cells. As is the case under Obama's current policy, the cells must be derived from leftover embryos at fertility clinics that would otherwise be discarded, and the donors must have given informed consent.

Congress should take up the issue speedily when it reconvenes mid-month. And if ever there was a time for scientists to let members of Congress and the public know what they think, it is now.

\section{How continents persist}

\section{Earth scientists have explained why Canada and South Africa are still here.}

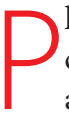
late tectonics paints a picture of Earth's mantle as a constantly changing sea of geological violence. Processes such as subduction and mantle convection mock the political boundaries imagined on the surface, as the ground we stand on is inevitably dragged back into the planet to be recycled as new territory elsewhere.

Yet amid this slow-motion destruction, blocks of Earth's crust have survived relatively unscathed for billions of years. Located at the core of continents such as North America and Australia, these cratons have been constants for much of the planet's history. Cratons are not new to science - their name can be traced back to 1921. But no one, until now, has been able to confirm how they remain in place for so long.

On page 78 of this issue, Anne Peslier and her colleagues offer a solution. After studying the southern African Kaapvaal craton, they conclude that water is the key. The deep roots of cratons are protected by a layer of unusually dry minerals, which resist the surrounding swirl of more fluid mantle. The findings are not completely unexpected. Water alters the viscosity of olivine, the most common mineral of the upper mantle. Geologists saw this as a likely way to preserve cratons.

This new study shows that they were correct. It was not easy work. To measure the water content of tiny grains of mineral demanded tremendous analytical skills. To retrieve the samples from deep underground in a pristine state took painstaking efforts. To combine the two to make a compelling scientific case marks a triumph for those involved.

The work may not make headlines, but it deserves recognition. Working in diamond country, they have established how some parts of our planet are forever. 